ACTA MYCOLOGICA

Vol. 42 (1): 119-123

2007
Dedicated to Professor Alina Skirgietto

on the occasion of her ninety-fifth birthday

\title{
New Phoma species on Leonurus cardiaca
}

\author{
BEATA ZIMOWSKA \\ Department of Plant Pathology, Agricultural University \\ Leszczyńskiego 7, PL-20-069 Lublin \\ beata.zimowska@ar.lublin.pl
}

Zimowsk a B.: New Phoma species on Leonurus cardiaca. Acta Mycol. 42 (1):119-123, 2007.

Two species of Phoma obtained from motherwort Leonurus cardiaca L., during mycological analyses attendant upon three-years study connected healthiness of the plants. Isolates of Phoma capitulum were obtained from roots, whereas Phoma septicidalis from roots and leaves. Description in vitro, photos of morphological structures and distribution of Phoma spp. are given. This is the first report of $P$. capitulum and $P$. septicidalis on motherwort in Poland.

Key words: Phoma, occurrence, morphology, Leonurus cardiaca

\section{INTRODUCTION}

Phoma spp. (Sphaeropsidales) constitute a group of fungi with very differentiated biological specialization (Marcinkowska 1995). They include saprophytic species, developing on different substrata, secondary pathogens of plants with polyphagous character of parasitism and specific pathogens of cultivated plants. The group of plants from which fungi from genus Phoma were isolated includes for example herbaceous plants (Machowicz-Stefaniak et al. 2002; Machowicz-Stefaniak et al. 2004). Phoma dictamnicola Boerema, de Gruyter et Noordel., P. glaucii Brun., P. multirostrata var. microspora (Allescher) Boerema from the leaves, stems and roots of common thyme, while P. eupatorii Died. was obtained from creemocarps (Machowicz-Stefaniak, Zimowska 2000; Machowicz-Stefaniak et al. 2002). P. exigua var. exigua Desm. and P. glomerata (Corda) Wollenw. et Hochapf. were isolated from the roots, stems and leaves of common thyme, common balm and St. John's wort (Zimowska, Mach owicz-Stefaniak 2004; M a chowicz-Stefaniak et al. 2004). Isolates of $P$. strasseri Moesz. were obtained from the stems and rhizomes of peppermint showing the signs of black rot (Zimowska, Machowicz-Stefaniak 2005).

In recent years the species of Phoma capitulum Pawer, Mathur et Thirumalachar (P. ostiolata var. ostiolata Pawer, Mathur et Thirumalachar, P. ostiolata var. brunnea Pawer, Mathur et Thirumalachar) as well as Phoma septicidalis Boerema 
(Pyrenoacheta telephii Alesch., Phoma telephii (Vestergr.) Kestern), which have not been described earlier, on this plant, have been isolated from Leonurus cardiaca $\mathrm{L}$. (de Gruyter, Noordeloos 1992; de Gruyter, Boerema 2002). In accessible literature these species are enumerated as commonly occurring saprotrophs developing on different substrata, and $P$. septicidalis can also cause necrosis of the leaves of plants from the family Gramineae (de Gruyter, Noordeloos 1992; de Gruyer, Boerema 2002).

Considering the key importance of Phoma spp. morphology, with the proper differentiation of taxa, the present paper deals with the identification of the enumerated two species of fungi made on the basis of thorough studies of macro- and microscopic properties of these organisms in cultures in vitro.

\section{MATERIAL AND METHODS}

The study material consisted of isolates Lc 186, Lc 259, Lc 368, Lc 544 and Lc 56 P. capitulum obtained from the roots and isolates Lc 238, Lc 79, Lc 139 and Lc 225 P. septicidalis from the roots and leaves of 2-year-old motherwort. The fungi cultures used were obtained as a result of the mycological analysis (Zimowska, Machowicz-Stefaniak 2004) accompanying the three-year-long studies (2004-2006) on plants' healthiness that were conducted on production plantation in the communes of Fajsławice and Dziecinin in the Lublin district (Zimowsk a unpublished).

Identification of the obtained isolates and the taxa they belong to was carried out on the basis of a thorough analysis of morphological structures, macroscopic properties of colonies and biochemical features conducted in vitro on standard media (maltose MA, oat agar OA and cherry agar CA) after 7 and 14 days of incubating the cultures in a thermostat at the temperature of $22^{\circ} \mathrm{C}$ (de Gruyter, Noordeloos 1992; Zimowska, Machowicz-Stefaniak 2005). The studied fungi cultures were marked on the basis of a monograph by de Gruyter and Noordeloos (1992) and de Gruyter and Boerema (2002).

\section{RESULTS}

The studies conducted on the growth of the analyzed isolates of $P$. capitulum on standard media showed that the cultures of the fungus on MA after 7 days reached the diameter of 38-40 mm, while after 14 days $75 \mathrm{~mm}$. The hyphae of the air mycelium formed a flocky structure of white or light olive-grey colour. The reverse was peach-salmon colour. The edge of cultures of all the studied isolates was characterized by regular growth. The growth of $P$. capitulum isolated on OA was slightly poorer than on MA since the diameter of the colony measured after 7 days was 36 $\mathrm{mm}$, while after 14 days it ranged from 65 to $70 \mathrm{~mm}$. The colonies were white-creamy with a salmon reverse, while the hyphae of the air mycelium formed a velvet-flocky structure. The smallest diameter of colonies was observed on medium CA. After 7 days it ranged from 27 to $29 \mathrm{~mm}$, while after 14 days - from 53 to $58 \mathrm{~mm}$. In the case of most isolates, on this medium the edge of a colony was characterized by irregular growth. The hyphae of the air mycelium were white and they formed a flocky structure. The reverse of the colony was of light salmon colour. 
Numerous pycnidia on OA centered in concentric circles or sectors. They were round, olive to olive-black, mostly smooth or covered with scarce hyphal outgrowths (Fig. 1). From 1 to 3 ostioles, from which grey conidial exudates, were observed on the surface of the pycnidia. The latter were mostly formed on the surface of agar or they were partly immersed in it. Their size was from 50 to $100 \mu \mathrm{m}$, on average (Tab. 1). The conidia were hyaline, round or slightly ellipsoidal, and they contained 1 to 2 guttules, their size ranging from 3.7 to $2.5 \mu \mathrm{m}$ (Fig. 2, Tab. 1). In the case of all the studied isolates of $P$. capitulum, the reaction with $1 \mathrm{~N} \mathrm{NaOH}$ was negative. Besides, none of the isolates formed chlamydospores.

After 7 days of growth $P$. septicidalis isolates on MA medium formed colonies with the diameter ranging from 20 to $38 \mathrm{~mm}$, while after 14 days the diameter ranged from 41 to $70 \mathrm{~mm}$. The hyphae of the air mycelium formed a compact felt-like structure of rosy-wine colour and the reverse of the same colour. A slightly bigger diameter was observed in the case of the growth of the colonies of $P$. septicidalis isolates on OA medium. After 7 days it ranged from 21 to $40 \mathrm{~mm}$, while after 14 days - from 50 to $57 \mathrm{~mm}$. The structure of the air mycelium was the same as on MA medium. The central part of the colony was olive-grey, while the edge had rosy-wine colour. On CA medium the fungus colonies reached the diameter from 20 to $29 \mathrm{~mm}$ after 7 days, while after 14 days it ranged from 40 to $60 \mathrm{~mm}$. The structure of the

Table 1

Characteryzation of pycnidia and conidia of Phoma capitulum and Phoma septicidalis (mean for 5 isolates)

\begin{tabular}{|c|c|c|c|c|c|c|}
\hline \multirow[t]{3}{*}{ Author } & \multicolumn{3}{|c|}{ P. capitulum } & \multicolumn{3}{|c|}{ P. septicidalis } \\
\hline & \multicolumn{2}{|c|}{ Pycnidia } & \multirow{2}{*}{$\begin{array}{c}\text { Conidia } \\
\text { shape and } \\
\text { dimension } \\
\text { in } \mu \mathrm{m}\end{array}$} & \multicolumn{2}{|c|}{ Pycnidia } & \multirow{2}{*}{$\begin{array}{c}\text { Conidia } \\
\text { shape and } \\
\text { dimension } \\
\text { in } \mu \mathrm{m}\end{array}$} \\
\hline & $\begin{array}{l}\text { shape and } \\
\text { dimension } \\
\text { in } \mu \mathrm{m}\end{array}$ & $\begin{array}{l}\text { arrangement } \\
\text { and structure } \\
\text { of walls } \\
\text { surface }\end{array}$ & & $\begin{array}{l}\text { shape and } \\
\text { dimension } \\
\text { in } \mu \mathrm{m}\end{array}$ & $\begin{array}{l}\text { arrangement } \\
\text { and structure } \\
\text { of walls } \\
\text { surface }\end{array}$ & \\
\hline Own data & $\begin{array}{l}\text { globose } \\
\text { with } 1 \text { to } 3 \\
\text { ostioles, } \\
50-100\end{array}$ & $\begin{array}{l}\text { on the agar } \\
\text { in concentric } \\
\text { zones or } \\
\text { sectors, with } \\
\text { softly hyphal } \\
\text { outgrowts }\end{array}$ & $\begin{array}{l}\text { globose } \\
\text { to shortly } \\
\text { ellipsoid, } \\
\text { with } 1 \text { to } 2 \\
\text { guttules, } \\
3.7 \times 2.5\end{array}$ & $\begin{array}{c}\text { globose } \\
\text { with } 1 \text { to } 2 \\
\text { ostioles } \\
65-160\end{array}$ & $\begin{array}{l}\text { mainly on the } \\
\text { agar but also } \\
\text { in the agar, } \\
\text { long setae } \\
\text { spread over } \\
\text { the surface }\end{array}$ & $\begin{array}{c}\text { ellipsoidal } \\
\text { with several } \\
\text { small } \\
\text { guttules, } 4.4 \\
\text { x } 2.2\end{array}$ \\
\hline $\begin{array}{c}\text { de Gruyter } \\
\text { and } \\
\text { Noordeloos } \\
1992\end{array}$ & $\begin{array}{c}\text { globose } \\
\text { with } 1 \text { to } \\
3 \text { ostioles, } \\
60-105\end{array}$ & $\begin{array}{l}\text { mostly on } \\
\text { the agar but } \\
\text { also partly } \\
\text { or entirely in } \\
\text { the agar in } \\
\text { concentric } \\
\text { zones or } \\
\text { sectors, } \\
\text { with hyphal } \\
\text { outgrowts }\end{array}$ & $\begin{array}{c}\text { broadly } \\
\text { and shortly } \\
\text { ellipsoid } \\
\text { with } 1 \text { to } 2 \\
\text { guttules, } 3.8 \\
\text { x } 2.6\end{array}$ & & & \\
\hline $\begin{array}{c}\text { de Gruyter } \\
\text { and } \\
\text { Boerema } \\
2002\end{array}$ & & & & $\begin{array}{l}\text { globose to } \\
\text { subglobose } \\
\text { with } 1 \text { to } \\
2 \text { ostioles, } \\
70-170\end{array}$ & $\begin{array}{l}\text { mainly on } \\
\text { the agar, } \\
\text { with long } \\
\text { setae spread } \\
\text { mainly over } \\
\text { the upper } \\
\text { surface }\end{array}$ & $\begin{array}{c}\text { subglobose } \\
\text { to } \\
\text { ellipsoidal } \\
\text { with several } \\
\text { small } \\
\text { or large } \\
\text { guttules, } 4.5 \\
\text { x 2.3 }\end{array}$ \\
\hline
\end{tabular}


air mycelium, the colour of the obverse and the reverse was similar to the colonies growing on OA medium. The edge of the studied isolates of $P$. septicidalis on all the three media was characterized by irregular growth.

Detailed observations on OA medium showed that the pycnidia of the studied fungus isolates got formed individually or in small groups. They were most frequently round, honey-olive to black-olive one, and their walls were covered by very numerous setae with the length ranging from 180 to $210 \mu \mathrm{m}$ (Fig. 3, Tab. 1). 1 to 2 ostioles, from which white drops of conidial exudates, were observed on the surface of the pycnidia. The size of the pycnidia ranged from 65 to $160 \mu \mathrm{m}$ (Tab. 1). The conidia were hyaline, 1-cell, ellipsoidal, with a few gutteles with the dimensions of $4.4 \times 2.2$ $\mu \mathrm{m}$ (Fig. 4, Tab. 1). In the case of all the studied isolates of $P$. septicidalis, the studies observed a positive reaction with $1 \mathrm{~N} \mathrm{NaOH}$ on MA and OA media. The edge of the colonies was of violet-purple. Besides, fragmentation of the mycelium cells characteristic of this species was visible on the hyphae of the mycelium, especially in older cultures (Fig. 5). None of the studied isolates of the fungus formed chlamydospores.

\section{DISCUSSION}

Thanks to the studies in vitro on the morphology of pycnidia and conidia and on the character of the growth of the analyzed cultures it was possible to distinguish two discussed species of Phoma and classify them into the proper sections. Results of the studies as compared to the descriptions contained in the monographs of fungi from the genus Phoma made it possible to place $P$. capitulum isolates in part I of Phoma section since they include studies on taxa with very small dimensions of conidia, with the length not exceeding $5.5 \mu \mathrm{m}$ (de Gruyter, Noordeloos 1992). Although the dimensions of the conidia in fungi from genus Phoma play a secondary diagnostic importance (Dorenbosch 1970), in the case of the species belonging to Phoma section this property acquires a special significance due to the division of this section into three parts performed on the basis of the conidia dimensions (de Gruyter, Noordeloos 1992; de Gruyter et al. 1993; de Gruyter et al. 1998). On the basis of a detailed analysis of morphological structures, especially pycnidia, the studied isolates of $P$. septicidalis were classified into the section of Paraphoma. A characteristic feature of the species described by the Dutch mycologists is the formation of pycnidia with the walls covered with setae, which are formed on their whole surface or they occur only around the ostiole (de Gruyter, Boerema 2002).

The conducted studies confirmed the correctness of the assumption presented in the 1930's and 1940's by Woollenweber, Hochapfel and Dennis (Den n is 1946), and later continued by the mycologists from a Dutch Station of Plant Protection in Wageningen (Boerema, Bollen 1975) that defining the taxa within Phoma spp. is possible only on the basis of constant morphological features that are observed in vitro in the cultures developing in standard conditions. 


\section{REFERENCES}

Boerema G. H., Bollen G. J. 1975. Conidiogenesis and conidial septation as differentiating criteria between Phoma and Ascochyta. Persoonia 8: 111-144.

De n n is R. W. G. 1946. Notes on some British fungi ascribed to Phoma and related genera. Trans. Br. Mycol. Soc. 29: 11-42.

Dorenbosch M. M. J. 1970. Key to nine ubiquitous soliborne Phoma- like fungi. Persoonia 6: $1-14$.

Gruyter J. de, Noordeloos M. E. 1992. Contributions towards a monograph of Phoma (Coelomycetes) I. 1. Section Phoma: Taxa with very small conidia in vitro. Persoonia 15 (1): 71-92.

Gruyter J. de, Noordeloos M. E., Boerema G. H. 1993. Contributions towards a monograph of Phoma (Coelomycetes) I. 2. Section Phoma: Additional taxa with very small conidia and taxa with conidia up to $7 \mu \mathrm{m}$ long. Persoonia 15 (3): 369-400.

Gruyter J. de, Noordeloos M. E., Boerema G. H.1998. Contributions towards a monograph of Phoma (Coelomycetes)-I. 3. Taxa with conidia longer than $7 \mu \mathrm{m}$. Persoonia 16 (4): 471-490.

Gruyter J. de, Boere ma G. H. 2002 . Contributions towards a monograph of Phoma (Coelomycetes) VIII. Section Paraphoma: Taxa with setose pycnidia. Persoonia 17 (4): 541-561.

Machowicz-Stefaniak Z., Zimowska B. 2000. Grzyby przenoszone przez nasiona roślin zielarskich. Acta Agrobot. 53 (2): 25-38.

Machowicz-Stefaniak Z., Zimowska B., Zalewska E. 2002. Grzyby zasiedlające różne organy tymianku właściwego Thymus vulgaris L. uprawianego na Lubelszczyźnie. Acta Agrobot. 55 (1): $185-197$.

Machowicz-Stefaniak Z., Zalewska E., Zimowska B. 2004. Grzyby zasiedlające nadziemne organy melisy lekarskiej (Melissa officinalis L.) i tymianku właściwego (Thymus vulgaris L.) uprawianych na Lubelszczyźnie. Folia Univ. Agric. Stein., Agriculture 239 (95): 229-232.

Marcin kowska J . 1995. Nowoczesne spojrzenie na systematykę rodzaju Phoma. Wiad. Bot. 39 (3/4): $47-52$.

Zimowska B., Machowicz-Stefaniak Z. 2004. Grzyby zagrażające uprawie dziurawca zwyczajnego (Hypericum perforatum L.) w województwie lubelskim. Acta Sci. Pol., Hortorum Cultus 3 (1): 61-74.

Zimowska B., Machowicz-Stefaniak Z. 2005. Charakterystyka izolatów Phoma strasseri nie notowanego w Polsce patogenu mięty pieprzowej (Mentha piperita L.). Acta Agrobot. 58 (2): $151-162$.

\section{Nowe gatunki z rodzaju Phoma na serdeczniku pospolitym}

\section{Streszczenie}

Podczas analizy mikologicznej towarzyszącej trzyletnim badaniom (2004-2006), nad zdrowotnością roślin serdecznika pospolitego (Leonurus cardiaca), uzyskano nie opisywane wcześniej na tej roślinie gatunki z rodzaju Phoma. Izolaty Phoma capitulum wyosobniono z korzeni, zaś Phoma septicidalis z korzeni i liści serdecznika pospolitego. Na podstawie szczegółowych obserwacji cech makroskopowych oraz mikroskopowych obserwowanych in vitro w kulturach na standardowych podłożach, izolaty $P$. capitulum zakwalifikowano do sekcji Phoma a izolaty P. septicidalis do sekcji Paraphoma. 


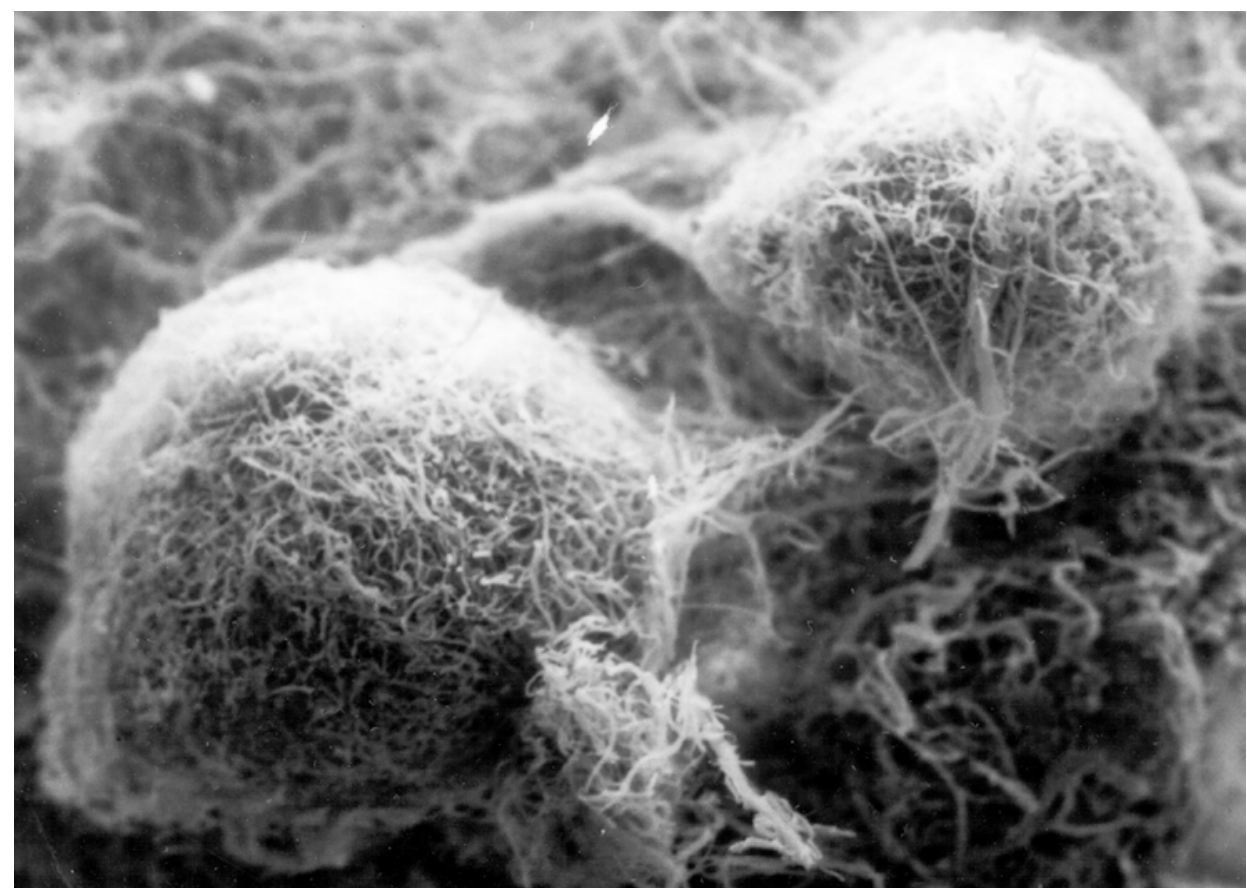

Fig. 1. Pycnidia of Phoma capitulum (SEM x 250). Phot. M. Wróbel.

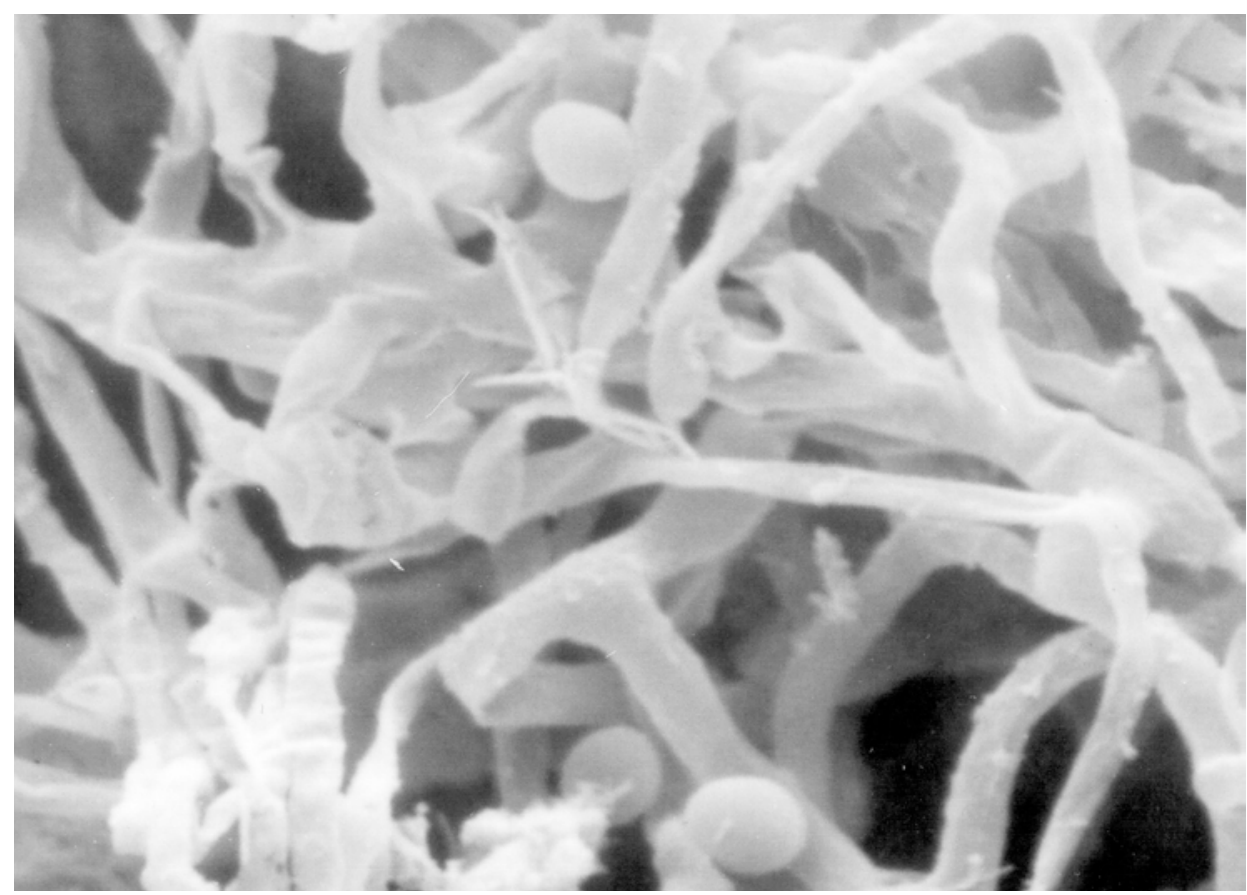

Fig. 2. Conidia of Phoma capitulum (SEM x 5100). Phot. M. Wróbel. 


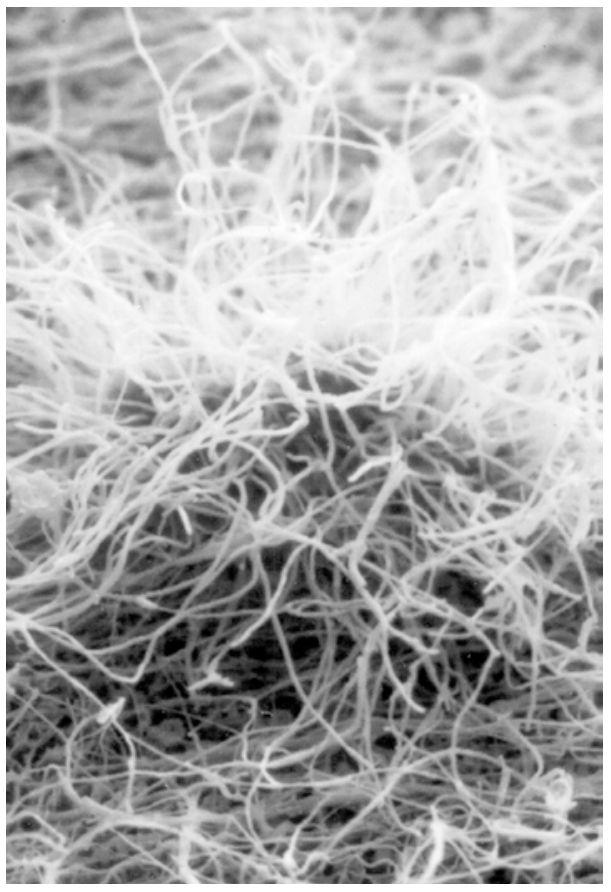

Fig. 3. Setose pycnidium of Phoma septicidalis (SEM x 300). Phot. M. Wróbel.

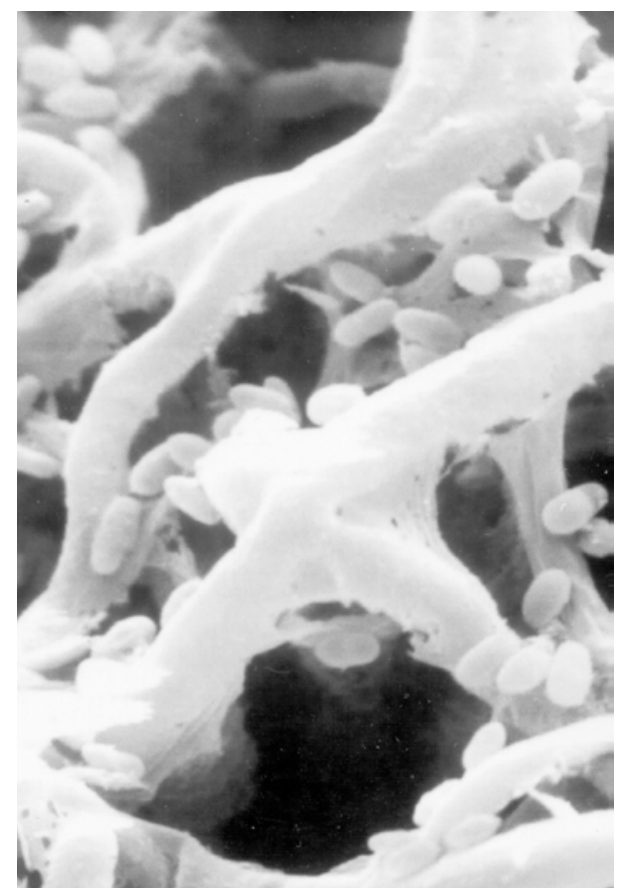

Fig. 4. Conidia of Phoma septicidalis (SEM x 2600). Phot. M. Wróbel.

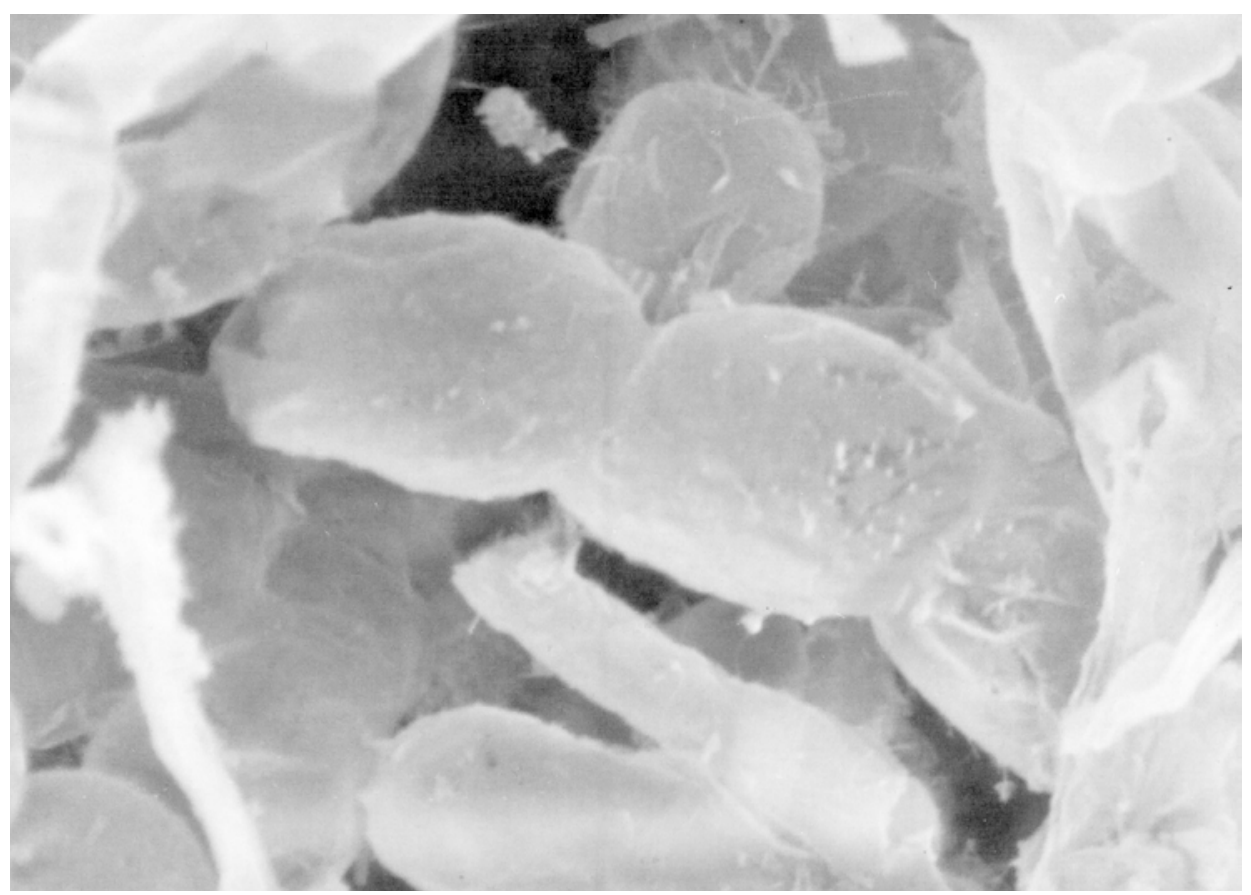

Fig. 5. Fragmentation of hyphae of Phoma septicidalis (SEM x 3000). Phot. M. Wróbel. 